\title{
Problematika bimbingan dan konseling bidang karier peserta didik SMA: A systematic literature review (SLR)
}

\author{
Astriandani Meitasari $\left.{ }^{1^{*}}\right)$, Emanuela Chyara Araceli Mulia ${ }^{2}$, Laila Ifrochatu Chasanah ${ }^{3}$, \& \\ Ma'rifatin Indah Kholili ${ }^{4}$ \\ Bimbingan dan Konseling, Universitas Sebelas Maret ${ }^{1234}$ \\ *) Alamat korespondensi: Jl. Ir. Sutami No. 36, Surakarta, 57126, Indonesia; E-mail: astriandani61@student.uns.ac.id
}

\begin{abstract}
Article History:
Received: 15/06/2021;

Revised: 21/06/2021;

Accepted: $21 / 06 / 2021$;

Published: 30/06/2021.
\end{abstract}

How to cite:

Meitasari, A., Mulia, E.C.A., Chasanah, L.I., \& Kholili, M.I. (2021). Problematika bimbingan dan konseling bidang karier peserta didik SMA: A systematic literature review (SLR).

Teraputik: Jurnal Bimbingan dan Konseling, 5(1), pp. 69-76. DOI:

10.26539/teraputik.51648

\begin{abstract}
Abstrak: Tujuan penelitian ini yaitu mengumpulkan dan menganalisa artikel-artikel terkait berbagai macam problematika BK yang dialami peserta didik SMA pada bidang karier. Metode yang digunakan dalam penelitian ini yaitu Systematical Literatur Review (SLR). Hasil dari penelitian ini terdapat berbagai macam problematika BK peserta didik SMA bidang karier yaitu rendahnya pengetahuan mengenai kurangnya perencanaan karier, tingginya kecemasan karier, kurang matangnya pemilihan karier, dan kurangnya pengetahuan mengenai pengambilan keputusan karier. Penyelesaian problematika karier ini yaitu layanan informasi karier berbasis life skills, bimbingan kelompok teknik modelling, terapi rasional emotif, peningkatan efikasi diri, peningkatan pemahaman self concept, konseling kelompok ekstensial humanistik, CDDQ (Career Decision-Making Difficulties Questionnaire), bimbingan klasikal karier dengan media PPT, konseling realitas, dan konseling teman sebaya. Saran untuk peneliti selanjutnya adalah upaya yang dilakukan untuk mengembangkan strategi yang efektif dan inovatif agar dapat digunakan sebagai alternatif penyelesaian problematika karier yang dialami peserta didik SMA.
\end{abstract}

Kata Kunci: Bimbingan dan Konseling, Problematika Karier

Abstract: This research aims to collect and analyze articles related to the various BK problems experienced by high school students in the career field. The method used in this research is Systematic Literature Review (SLR). The results of this research include a variety of high school career issues such as low knowledge of career planning deficiencies, high career anxiety, lack of maturity, and lack knowledge of career decisions. Career-based career information services, coaching of modelling techniques, emotional, rational therapy, improved self-effectiveness, concept improvement consulting, CDDQ, career classic guidance with a PPT, reality counselling, and counselling friends of your own. Advice for further research to develop an effective and innovative strategy to be used as an alternative to the problematical career path experienced by high school students.

Keywords: Guidance and Counselling, Career Problematic

provided the original work is

properly cited. (C) 2021,

Meitasari, A., Mulia, E.C.A.,

Chasanah, L.I., \& Kholili, M.I. (s).

\section{Pendahuluan}

Bimbingan dan konseling komprehensif merupakan bagian dari pendidikan yang ada di Indonesia. Suherman (2011:5) menegaskan bimbingan komprehensif merupakan pandangan mutakhir yang bertitik tolak dari asumsi yang positif tentang potensi manusia. Berdasarkan asumsi inilah bimbingan dipandang sebagai suatu proses memfasilitasi perkembangan yang menekankan kepada upaya membantu semua peserta didik dalam semua fase perkembangannya. Selama ini bimbingan sering dipandang sebagai kegiatan layanan yang mengedepankan penyembuhan atau pemecahan masalah. Padahal selain itu bimbingan berfungsi pencegahan, pendidikan dan pengembangan.

Bimbingan dan konseling memilki peran untuk membantu individu di berbagai rentang usia kehidupannya, khususnya pada masa remaja. Masa remaja adalah sebuah masa peralihan dari masa kanak-kanak menuju dewasa yang dapat ditandai dengan munculnya kematangan pada aspek-aspek seperti aspek fisik, aspek psikologis, aspek psikomotorik hingga aspek kognitifnya. Hal ini di dukung dengan pernyataan dari Santrock (2011) yang mengungkapkan 
bahwa masa remaja adalah masa peralihan perkembangan individu dari masa kanak-kanak menuju masa dewasa yang dimulai dari usai sekitar 10-12 tahun dan akan berakhir pada usia sekitar 18-22 tahun.

Remaja memiliki bermacam-macam tugas perkembangan, salah satunya pada bidang karier. Hal ini sesuai dengan pendapat Havighurst (Saifudin, 2018:2) yang mengungkapkan pendapatnya mengenai tugas perkembangan untuk setiap individu yang masuk kedalam kategori remaja untuk dapat memilih dan mempersiapkan karier masa depannya. Super (Sharf, 2013) menambahkan bahwa remaja dalam bidang karier berada pada tahap eksplorasi. Tahap eksplorasi ini diketahui memiliki rentang usia sekitar 15-24 tahun. Tahap-tahap pada eksplorasi ini memiliki kegiatan awal yaitu menggabungkan berbagai informasi (cristallizing) yang fokusnya terarah pada pengambilan keputusan karier (specifying), hal ini menjadi pertimbangan dalam pengambilan keputusan karier yang sesuai dengan keinginan (implementing).

Berdasarkan penjelasan diatas disimpulkan bahwa bimbingan dan konseling karier perlu diberikan kepada peserta didik dalam mencapai tugas perkembangannya untuk memilih dan mempersiapkan karier untuk masa depanya. Bimbingan dan konseling karier diharapkan dapat meningkatkan pengetahuan peserta didik tentang dirinya sendiri sehingga dapat menentukan arah karier dengan mandiri dan tepat sesuai dengan bakat dan minatnya. Pemberian layanan bimbingan dan konseling karir juga diharapkan dapat meningkatkan kemampan dan pemahaman, pengelolaan, penghargaan dan pengarahan diri serta dapat mengatasi masalah dalam kehidupan sehari-hari.

Hasil kajian teori tersebut diselaraskan dengan melakukan wawancara kepada guru BK. Hasil wawancara yang telah dilakukan kepada praktisi disekolah juga mendapatkan temuan menarik terkait implementasi layanan untuk meningkatkan pemahaman karier siswa. Wawancara dilakukan pada bulan Mei 2020 dengan tujuan untuk mengetahui pelaksanaan layanan karier yang biasa dilakukan di sekolah. Menurut pernyataan guru BK tersebut diketahui bahwa sekolah tempai beliau mengajar berusaha semaksimal mungkin memberikan layanan karier. Beberapa kegiatan yang dilakukan misalnya menerapkan sistem Kegiatan Tengah Semester (KTS) untuk melakukan kunjungan. Kegiatan kunjungan tersebut misalnya ke salah satu wirausaha di Jogja, kunjungan ke Universitas Gajah Mada, mengunjungi perusahaan-perusahaan besar seperti perusahaan Pocari Sweat. Kunjungan ke tempat-tempat tersebut dapat memberi motivasi dan gambaran kepada peserta didik terkait pilihan karier melanjutkan jenjang yang lebih tinggi. Kegiatan kunjungan KTS juga

Harapannya setiap siswa mampu mencapai tahapan perkembangan karier, namun faktanya masih sering ditemui kendala yang dialami oleh siswa. Seperti hasil penelitian Budiningsih (2020) di SMA Negeri 1 dan SMA Negeri 2 Pariaman mengungkap permasalahan kurang matangnya perencanaan karier peserta didik. Penelitian yang dilakukan pada tahun 20120 ini melibatkan 20 orang peserta didik kelas XI. Hasil penelitian tersebut adalah: 1) peserta didik masih mengalami kebingungan saat akan memutuskan jenis pendidikan lanjutan; 2) peserta didik tidak mengetahui prospek dan dunia kerja; 3) informasi karier di sekolah yang belum memadai; 4) peserta didik masih ada yang belum mengetahui potensi diri; 5) pemilihan karir masih bergantung dengan keadaan ekonomi ke dua orang tuanya; 6 ) berpandangan bahwa karir yang paling baik yaitu menjadi seorang Pegawai Negeri Sipil (PNS).

Tentu saja problematika karier yang dialami peserta didik SMA tidak hanya sebatas itu saja. Sehingga berdasarkan latar belakang dan temuan awal tersebut, peneliti tertarik untuk melakukan kajian yang lebih dalam terkait problematika bimbingan dan konseling khususnya pada bidang karier yang dialami oleh peserta didik SMA.

\section{Metode}

Jenis penelitian adalah systematical literatur review. Kitchenham (Siswanto, 2010) menjelaskan bahwa systematic literature review adalah suatu metode penelitian untuk melakukan identifikasi, evaluasi dan interpretasi terhadap semua hasil penelitian yang relevan terkait pertanyaan penelitian tertentu, topik tertentu, atau fenomena yang menjadi perhatian. 
Siswanto (2010) lebih lengkap menyebutkan bahwa systematical review akan sangat bermanfaat untuk melakukan sintesis dari berbagai hasil penelitian yang relevan, sehingga fakta yang disajikan kepada penentu kebijakan menjadi lebih komprehensif dan berimbang.

Systematical review dalam penelitian ini dilaksanakan dengan menghimpun artikel-artikel bimbingan dan konseling dari tahun dari tahun 2010 Sampai tahun 2020. Sebagian besar artikel diperoleh dari jurnal-jurnal bimbingan dan konseling serta pendidikan, baik jurnal nasional maupun jurnal internasional. Artikel yang dikumpulkan antara lain diperoleh dari Jurnal Fokus, Jurnal Bimbingan dan Konseling Terapan, Jurnal Psikologi Pendidikan \& Konseling, Jurnal Bimbingan dan Konseling, Consilia: Jurnal Ilmiah Bimbingan dan Konseling, Psikopedagogia, American International Journal of Social Science, Counselor Education, Asian Journal of Education and Social Studies. Jumlah artikel awal yang ditemukan 36 artikel. Peneliti hanya mengambil 21 artikel yang disesuaikan dengan (1) Fokus bidang karier, (2) kesesuaian dengan pertanyaan penelitian, (3) membahas probelmatika di jenjang pendidikan SMA.

Prosedur penelitian systematical review dengan pendekatan kualitatif dilaksanakan dengan mengikuti langkah-langkah menurut Francis \& Baldesari (2006). Adapun teknis kegiatan yang dilakukan dideskripsikan dalam tabel di bawah ini.

Tabel 1. Langkah Penelitian

Langkah penelitian menurut Langkah yang dilakukan peneliti

Francis \& Baldesari (2006)

1) Memformulasikan pertanyaan (formulating the review question) a) Merumuskan pertanyaan penelitian yang difokuskan pada problematika bidang karier peserta didik di jenjang Pendidikan SMA

b) Dilanjutkan dengan pertanyaan berikutnya yaitu upaya yang dilakukan oleh guru bimbingan dan konseling / peneliti sebelumnya dalam mengatasi problematika tersebut.

2) Melakukan pencarian a) Melakukan pencarian literatur di berbagai jurnal. literatur systematial review b) Fokus utama adalah jurnal-jurnal Pendidikan serta jurnal (conducting a systematical literature search)

3) Melakukan skrining dan Skrining dan seleksi dilaksanakan dengan memperhatikan seleksi artikel penelitian tujuan. yang cocok (screening and Artikel yang menyajikan data problematika bidang karier selecting research articles)

4) Melakukan analisis dan Analisis dilakukan dengan membandingkan masing-masing sintesis temuan-temuan kualitatif (analyzing and synthesizing qualitative)

5) Memberlakukan kendali Kendali mutu dilakukan dengan melakukan konsultasi mutu (maintaining quality kepada dosen bimbingan dan konseling. control)

6) Menyusun laporan akhir (presenting findings)
Laporan akhir dilaksanakan dengan menulis artikel hasil penelitian kemudian dipublikasikan.

Proses analisis data dalam penelitian ini menggunakan metode meta-sintesis. Siswanto (2010) mengungkapkan bahwa dalam systematical literature review terdapat dua jenis metode yaitu metode meta-analisis dan meta-sintesis. Pada penelitian ini menggunaka teknik analisis datra meta-sintesis dengan melakukan integrasi data untuk mendapatkan teori maupun konsep baru atau tingkatan pemahaman yang lebih mendalam dan menyeluruh (Perry \& Hammond, 2002). Meta sintesis bertujuan untuk menjawab pertanyaan penelitian dengan cara merangkum berbagai hasil penelitian. 


\section{Hasil dan Diskusi}

Problematika karier yang dialami peserta didik sangat sering ditemui. Konselor atau guru BK menggunakan berbagai cara untuk menyelesaikan problematika karier yang dihadapi peserta didik. Seperti halnya penyelesaian problem karier menggunakan kurikulum bimbingan yang biasa maupun dalam bentuk modifikasi yang menggunakan tambahan media atau metode yang lain.

Berdasarkan hasil penelitian diketahui ada enam problematika bimbingan dan konseling bidang karier pada peserta didik SMA. Empat problematika ini diperoleh dari 21 artikel. Problematika tersebut yaitu : (1) rendahnya pemahaman karier, (2) kurangnya perencanaan karier, (3) kecemasan karier tinggi, , dan (4) kurangnya pengetahuan mengenai pengambilan keputusan karier.

Problematika pertama terkait rendahnya pemahaman karier yang dikemukakan oleh Hartono, Musdalifah (2019) pemahaman karier merupakan suatu perihal penting yang menjadi kebutuhan peserta didik untuk ditingkatkan sebagai upaya untuk mengambil keputusan karier yang sesuai bagi peserta didik. Hal ini selaras dengan pendapat dari Hartinah, Wibowo, Tadjri (2015) yang mengemukakan bahwa pesrta didik tidak dapat menentukan karier masa depan mereka apabila mereka tidak memiliki pemahaman terhadap karier yang ingin mereka ambil sejak dini.

Problematika kedua yaitu kurangnya perencanaan karier, pada hakikatnya peserta didik yang tidak memiliki kesiapan untuk memiliki rencana karier, mereka akan mengalami kesulitan dalam memilih karier di masa depan mereka. Apriansyah, Hadiwinarto, Mishbahudin (2018), Nugroho, Supriatno, Budiamin (2017), Arifin (2015), Fasha, Sinring, Aryani (2015), dan Utomo (2015) dalam penelitian mereka masing-masing sepakat bahwa mengambil keputusan karier adalah tugas perkembangan berat yang perlu dipertimbangkan secara matang oleh peserta didik dan apabila peserta didik tidak mampu mengambil mengambil keputusan karier dengan benar, maka hal ini akan mempengaruhi masa depan peserta didik.

Selanjutnya problematika yang ketiga adalah kecemasan karier yang tinggi, munculnya rasa cemas pada peserta didik usia SMA adalah suatu perasaan wajar yang muncul pada saat perkembangan mereka. Istirahayu, Mayasari, Fitriadi, Damayanti (2018) menyebutkan dalam penelitiannya bahwa banyak ditemukan peserta didik SMA yang masih kebingungan dalam memilih karier mereka dan merasa cemas akan pilihan yang mereka tuju karena tidak sesuai dengan mereka melainkan tuntutan dari orang tua mereka. Berdasarkan hal ini, kecemasan yang muncul akan memunculkan rasa khawatir yang tinggi bagi mereka sehingga tidak bisa memikirkan keputusan yang tepat untuk diri mereka sendiri.

Kemudian yang terakhir adalah berkaitan dengan kurangnya pengetahuan mengenai pengambilan keputusan karier, hal ini dibuktikan oleh Arifin (2015) Ketidakmampuan peserta didik dalam memilih, menentukan serta memutuskan arah pilihan kariernya selingkali disebabkan oleh kurangnya informasi yang diberikan oleh guru BK mengenai program studi atau jurusan yang ada di perguruan tinggi san pekerjaan yang cocok serta sesuai dengan minat dan kemampuannya. Kurangnya jam mengajar guru BK dan terbatasnya waktu meman seringkali menjasi alasan tidak terlaksananya layanan BK di sekolah, akan tetapi seharusnya hal ini tidak dijadikan sebagai penghambat dalam melakukan layanan bimbingan atau informasi karir kepada peserta didik. Hasil analisis kebutuhan yang dilakukan kepada peserta didik kelas XII SMA N 3 Makassar, diperoleh hasil bahwa mereka belum dapat mengambil keputusan karier dan masih bingung dalam menentukan pilihan jurusan serta memilih pekerjaan yang sesuai.

Berdasarkan hasil yang telah tersaji di atas, dianalisis masing-masing problematika bersama dengan solusi yang dituliskan oleh peneliti sebelumnya.

1. Rendahnya pemahaman karier

Problematika rendahnya pemahaman karier peserta didik SMA diperoleh dari penelitian yang dilakukan oleh Hartono \& Musdalifah (2009). Hasil penelitiannya menunjukkan bahwa pemahaman peserta didik SMA mengenai karier masih rendah. Padahal pemahaman karier merupakan aspek penting sehingga perlu ditingkatkan untuk membantu peserta didik agar mampu mengambil keputusan karier. Rendahnya pemahaman karier ini diatasi dengan menggunakan bimbingan klasikal. Bimbingan klasikal diberikan kepada 183 peserta didik kelas XII IPA 1, XII IPA 2, XII IPA 3, XII IPS 
1, XII IPS 2, dan XII IPS 3 SMA Intensif Taruna Pembangunan Surabaya. Hasilnya menunjukkan bahwa bimbingan klasikal karier menggunakan media PowerPoint berbasis object superiority effect tidak dapat meningkatkan pemahaman karier siswa SMA. Hartinah, Wibowo, Tadjri (2015) menawarkan solusi yang berbeda terkait problematika ini, dalam penelitian yang mereka lakukan di SMA N 8 Pontianak peneliti menerapkan layanan informasi karier berbasis life skill pada siswa kelas $X$ dan hasilnya menunjukkan bahwa model ini layak untuk diterapkan di lapangan dan efektif guna meningkatkan pemahaman dalam merencanakan karier peserta didik.

2. Kurangnya perencanaan karier

Terdapat enam penelitian yang berfokus pada problematika perencanaan karier yaitu Setyowati \& Surtanti (2020); Teknik modeling dalam bimbingan kelompok dengan tujuan membatu merencanakan karier peserta didik, dapat membantu dalam menentukan pilihan kariernya dengan melihat model-model yang dapat membantu untuk menemukan pilihan karier mereka dan menjadikan sosok model tersebut dapat dijadikan sebagai contoh kehidupan masa depannya. Dibuktikan dengan penelitian yang dilakukan oleh Rahmatyana \& Irayant (2020)) menunjukkan bahwa teknik modeling dalam bimbingan kelompok untuk membantu perencanaan karier peserta didik menunjukkan hasil positif, dan efektif terbukti adanya perbedaan yang signifikan tentang arahan perencanaan karier peserta didik setelah diberikan treatment dari hasil pelaksanaan pretest dan postest. Kemudian untuk solusi dari segi teknologi, Zafar (2019); Pengembangan media blog sebagai sarana informasi untuk meningkatkan kemampuan dalam perencanaan karier peserta didik di SMA Negeri 1 Bulukumba ini berawal dari tidak adanya jam khusus bagi guru pembimbing SMA Negeri 1 Bulukumba yang mengakibatkan peserta didiknya tidak memberoleh informasi yang sesuai. Oleh sebeb itu, peneliti Fatmayanti (2015) berinisiatif untuk mengembangkan media blog sebagai sarana informasi karier. Blog tersebut memuat mengenai informasi mengenai cara merencanakan karir, informasi mengenai jenis-jenis studi lanjut, kode etik pelaksanaan BK di sekolah, penjelasan mengenai apa itu bimbingan karir serta pentingnya bagi siswa dan juga layanan tanya jawab yang memungkinkan siswa untuk memberikan pertanyaan seputar karir tanpa bertemu langsung dengan guru BK. Adanya blog tersebut dapat dikatakan efektif sebagai sarana informasi dalam meningkatkan kemampuan perencanaan karir di SMA Negeri 1 Bulukumba berdasarkan hasil uji lapangan dan hasil uji coba produk oleh beberapa ahli.

3. Kecemasan karier tinggi

Kecemasan dalam memilih karier adalah problematika yang sering dialami oleh peserta didik SMA. Dimana problematika ini menurut Qareeba \& Duntari (2019) dapat diatasi menggunakan layanan bimbingan karier yang mana telah diterapkan kepada 2 peserta didik SMA N 2 Cimahi mampu mengurangi kecemasan karier yang dialami peserta didik. Tingginya kecemasan pada peserta didik dalam menetukan arah peminatan ketika Penerimaan Peserta Didik Baru (PPDB) menurut peneliti Wijaya (2014) dapat diselesaikan melalui layanan konseling kelompok dengan model eksistensial humanistic. Pendekatan eksistensial humanistik merupakan strategi yang tepat untuk membantu peserta didik dalam mengurangi kecamasannya. Sehingga melalui layanan konseling kelompok dengan pendekatan ini dapat membantu peserta didik dalam mengurangi kecemasan. Kelayakan model ini telah divalidasi oleh dua pakar bimbingan dan konseling serta sepuluh oraang praktisi atau guru BK atau Konselor bahwa model konseling kelompok eksestensial humanistic efektif dalam mengurangi kecemasan peserta didik menentukan arah peminatan.

4. Kurangnya pengetahuan mengenai pengambilan keputusan karier.

Apriansyah, Hadiwinarto, Mishbahudin (2018) Melalui konseling realitas, individu menanamkan cita-cita mereka sesuai dengan keinginan dan sistem kepercayaan yang mengatur perilaku tersebut. Dengan konseling realitas dapat membantu peserta didik berkomintmen dalam melaksanakan action sehinggda dapat keluar dari masalahnya. Arifin (2015) Ketidakmampuan peserta didik dalam memilih, menentukan serta memutuskan arah pilihan kariernya selingkali disebabkan oleh kurangnya informasi yang diberikan oleh guru BK mengenai program studi atau jurusan yang ada di perguruan tinggi 
san pekerjaan yang cocok serta sesuai dengan minat dan kemampuannya. Kurangnya jam mengajar guru BK dan terbatasnya waktu meman seringkali menjasi alasan tidak terlaksananya layanan BK di sekolah, akan tetapi seharusnya hal ini tidak dijadikan sebagai penghambat dalam melakukan layanan bimbingan atau informasi karir kepada peserta didik. Hasil analisis kebutuhan yang dilakukan kepada peserta didik kelas XII SMA N 3 Makassar, diperoleh hasil bahwa mereka belum dapat mengambil keputusan karier dan masih bingung dalam menentukan pilihan jurusan serta memilih pekerjaan yang sesuai, sehingga mereka sangat membutuhkan layanan informasi dengan model layanan informasi karier berbasis media elektronik (e-career). Hal inilah yang membuat peneliti Fasha, Sinring, Aryani (2015) melakukan penelitian pengembangan layanan informasi karier berbasis media elektronik (e-cereer) untuk membantu meningkatkan keputusan karier peserta didik di SMA N 3 Makassar.

\section{Simpulan}

Bimbingan dan konseling karier merupakan suatu pemberian informasi dari konselor atau guru BK kepada konseli atau peserta didik terkait dengan problematika karier. Problematika karier rupanya tidak hanya dirasakan oleh peserta didik tingkat SMA di Indonesia saja melainkan di luar negeri juga merasakan. Problematika karier yang dihadapi antara lain berupa pentingnya konseling karier dengan solusi mengikuti bimbingan karier dan pemberian layanan informasi, kecemasan karier dengan solusi meneraptakan teknik Rational Emotive Behavior dan bimbingan karier, pemilihan karier dengan menggunakan tekink self concept dan bimbingan kelompok, kematangan karier dengan menggunakan layanan informasi berbasus model multimedia, perencanaan karier dengan solusi penerapan teknik modeling dalam bimbingan kelompok, menggunakan CCDQ (Career Decision-Making Difficulties Questionnaire) dalam konseling karier, pengambilan keputusan karier dengan solusi menggunakan bimbingan kelompok dengan teknik fishbowl. Untuk peneliti selanjutnya, peneliti menyarankan untuk lebih mengembangkan beberapa cara yang efektif dan inovatif yang kemudian dapat digunakan sebagai penyelesaian problematika karier yang dialami peserta didik SMA sederajat.

\section{Ucapan Terima Kasih}

Terima kasih peneliti ucapkan kepada Ma'rifatin Indah Kholili, M.Pd selaku Dosen Program Studi Bimbingan dan Konseling yang juga merupakan dosen pembimbing dalam penulisan artikel ini karena sudah memberikan arahan, masukan, dan dukungan sehingga dapat terselesaikannya penulisan artikel ini. Pihak lainnya yang merupakan tim peneliti ingin mengucapkan terima kasih banyak atas partisipasi dan kerja kerasnya dalam menyelesaikan artikel ini dengan baik.

\section{Daftar Rujukan}

Apriansyah, A. Hadiwidianto. \& Mishbahuddin, A. (2018) Hubungan Antara Efikasi Diri dengan Kemampuan Pengambilan Keputusan Karir Siswa MAN 2 Kota Bengkulu. Consilia, 3(1).

Arifin, A. A., \& Saleh, I. (2015). Teknik Two Stay Two Stray dalam Bimbingan Kelompok untuk Meningkatkan Wawasan Siswa dalam Pemilihan Jurusan Di Perguruan Tinggi. Jurnal Psikologi Pendidikan \& Konseling, 1(1), 19-27.

Athiyah, I., Tadjri, I., \& Purwanto, E. (2014). Career Information Service Model Multimedia- Assisted For Increasing Students Career Maturity. Jurnal Bimbingan Konseing, 3(1), 16-21. 
Budiningsih, T. E. (2020). Perlukah Perencanaan Karier pada Siswa SMA Studi Korelasi Konsep Diri dan Perencanaan Karier Siswa SMA Negeri 1 Sulang. Intuisi: Jurnal Psikologi IImiah, 11(3), 245-252.

Corey, G. (2009). Teori dan Praktik Konseling dan Psikoterapi. Bandung: PT Refika Aditama

Corey, G. (2012). Teori dan Teknik Konseling dan Psikoterapi. Terjemahan oleh E. Koeswara. (2009). Bandung: PT. Refika Aditama

Duntari, R. A. A. (2018). Strategi Perencanaan Karier Remaja Melalui Peningkatan Pemahaman Self Concept. FOKUS, 1(3). 117-123

Fasha, F., Sinring, A., \& Aryani, F. (2015). Pengembangan Model E-Career untuk Meningkatkan Keputusan karir Siswa SMA Negeri 3 Makassar. Jurnal Psikologi Pendidikan \& Konseling, 1(2), 170-179

Fatmayanti, A. (2015). Pengembangan Media Blog Sebagai Sarana Informasi untuk Meningkatkan Kemampuan Perencanaan Karir Di SMAN 1 Bulukumba. Jurnal Psikologi Pendidikan \& Konseling, 1(2), 163-169

Germeijs, V., \& Verschueren, K. (2006). High School Students' Career Decisionmaking Process: A Longitudinal Study Of One Choice. Journal Of Vocational Behavior, 68:189-204.

Hartinah, G., Wibowo, M. E., \& Tadjri, I. (2015). Pengembangan Model Layanan Informasi Karir Berbasis Life Skills untuk Meningkatkan Pemahaman dalam Perencanaan Karir Siswa SMA. Jurnal Bimbingan Konseling, 4(1), 43-48

Hartono \& Mudalifah, A. (2019). Layanan Klasikal Bimbingan Karier dengan Media PPT Berbasis Object Superiority Effect untuk meningkatkan Pemahaman Diri dan Pemahaman Karier Siswa SMA. Jurnal Bimbingan dan Konseling Terapan, 3 (1), 1-13

Hilling, E. (2017). The Importance of Career Counseling and Post Secondary Readiness for High School Students. Counselor Education. New York: The College at Brockport.

Istirahayu, I., Mayasari, D., Fitriyadi, S., \& Damayanti, Z. (2018). Bimbingan Karir Terhadap Pemilihan Studi Lanjut Siswa Kelas XII. Jurnal Bimbingan dan Konseling Terapan, 2(2), 139-144.

Loan, D.T.B. \& Van, N.T. (2015). Career Guidance in Secondary Schools - A Literature Review and Strategic Solutions for Vietnamese Rural Areas. American International Journal of Social Science.

Maulana, R. \& Fauzi, S. A. (2019). Penerapan Terapi Rasional Emotif (TRE) dalam Mengurangi Kecemasan Siswa Menentukan Karier. FOKUS, 2(2), 57-64

Mubiana, Precious Bupe. (2010). Career Maturity, Career Knowledge, and Self Knowledge among Psychology Honours Students: an Exploratory Study. Disertasi. Afrika Selatan: University of Pretoria.

Nevid S.J, Spencer, A.R \& Beverly. R. (2003). Psikologi Abnormal. Jakarta: Erlangga

Nugroho, A. R., Supriatna, M., \& Budiamin, A. (2017). Model Konseling Realitas untuk Mengembangkan Keterampilan Pengambilan Keputusan Karier. PEDAGOGIA, 6(2), 119-124

Prabowo, W., Yusuf, M., \& Setyowati, R. (2019). Pengambilan Keputusan Menentukan Jurusan Kuliah Ditinjau Dari Student Self Efficacy Dan Persepsi Terhadap Harapan Orang Tua. Jurnal Psikologi Pendidikan \& Konseling, 5(1), 42-48 Press

Qareeba, P. L., \& Duntari, R. A. A. (2019). Layanan Bimbingan Karier untuk Mengurangi Kecemasan Siswa SMA Menghadapi Ujian Nasional. FOKUS, 2(1), $17-23$ 
Rahmatyana, N., \& Irmayanti, R. (2020). Teknik Modeling dalam Bimbingan Kelompok untuk Perencanaan Karier Siswa SMA. FOKUS, 3(2), 61-71

Rahmawati, W. K., Ahmad, A. (2019). Faktor- Faktor yang Mempengaruhi Minat Siswa Memilih Sekolah Di SMA Nuris Jember. Jurnal Bimbingan dan Konseling Terapan, 3(1), 38-49

Saifuddin, A. (2018). Kematangan Karier Teori dan Strategi Memilih Jurusan dan Merencanakan Karier.Yogyakarta: Pustaka Belajar

Santrock, J. W. (2011). Life Span Development (5th ed.). Jakarta: Erlangga.

Sharf, R. (2013). Applying Career Development Theory to Counseling (6th ed.). Boston: Thomas Brooks/Cole

Siswanto. (2010). Systemic Review sebagai Metode Penelitian untuk Mensintesis HasilHasil Penelitian (Sebuah Pengantar). Surabaya: Pusat Penelitian dan Pengembangan Sistem dan Kebijakan Kesehatan.

Sugiyanto. (2004). Hand-out Meta-Analysis. Yogyakarta: Fakultas Psikologi UGM.

Suherman. (2011). Manajemen Bimbingan dan Konseling. Bandung: Rizqi Press.

Ulfiah (2009), Hakikat Perkembangan Dalam Konseling, Bandung: Fakultas Psikologi UIN Sunan Gunung Djati Bandung .

Utomo, L. Z. (2015). Model Bimbingan Kelompok dengan Teknik Fishbowl untuk Mengembangkan Keterampilan Pengambilan Keputusan. Jurnal Bimbingan Konseling, 4(1), 1-7.

Wahyudin. (2009). Aplikasi Multimedia. Bandung: Politeknik Telkom Bandung

Wijaya, R. S. (2014). Model Konseling Kelompok Eksistensial Humanistik untuk Mengurangi Kecemasan Siswa Menentukan Arah Peminatan SMA Negeri Semarang. 3 (2). 83-89.

Winkel, W.S., Hastuti, M.M., (2006). Bimbingan dan Konseling di Instansi Pendidikan. Yogyakarta: Penerbit Media Abadi.

Yusuf, S., Nurihsan, J. (2005). Landasan Bimbingan dan Konseling. Bandung: PT Remaja Rosda Karya.

Zafar, M. (2019) . Career Guidance in Career Planning among Secondary School Students. Asian Journal of Education and Social Studies.Malaysia: Universiti Malaysia Kelantan.

Zunker, V.G. (2008). Career Counselling: A Holistic Approach (ed.7). USA: Thomson Brooks/Cole Publishing Com.

\section{Competing interests:}

The authors declare that they have no significant competing financial, professional or personal interests that might have influenced the performance or presentation of the work described in this manuscript. 